\title{
De pedagogia, acció comuna i esperança: I'aposta del professor Josep Maria Puig per educar en i per a una altra manera de viure
}

\author{
Eric Ortega González (Universitat de Barcelona)
}

Puig Rovira, Josep M. Pedagogía de la acción común.

Barcelona, Editorial Graó, 2021, 170 pàgs.

D'entrada cal advertir que aquesta nota de lectura està viciada des d'un bon començament. En efecte, el llibre sobre el que m'ocuparé ha sortit de la formidable ploma de Josep Maria Puig, professor, ara jubilat, de la Facultat d'Educació de la Universitat de Barcelona i primer professor, ara ja fa una pila d'anys, d'un servidor. Aquest fet, que no té per què restar objectivitat al que diré, sí que ha de deixar entreveure la simpatia i l'afecte que professo per l'home que, en arribar la primera classe del Grau de Pedagogia que hom havia de viure, ens esperava a l'aula 201, en el marc de l'assignatura de Teoria de l'Educació, amb una pregunta que tenia per voluntat no deixar ningú indiferent: els animals s'eduquen?

D'això, com deia, ja fa un bon grapat d'anys i les facècies i les diverses mostres de bonhomia d'en Puig, com alguns companys agraden en dir-li, s'han anat succeint a la seva manera: gairebé desapercebudes i sense estridències. Per aquesta raó, tot i que la ressenya busca fer justícia al text que ens ocupa, el lector atent no podrà deixar d'advertir l'admiració intel.lectual i humana sentida per qui fa $i$ ha fet molt i bé per l'educació moral al nostre país, i per qui amb Pedagogía de la acción común ens ofereix una esplèndida síntesi del seu pensament a través d'un llibre en què basteix metateòricament les qüestions i les propostes metodològiques sobre les que ha estat treballant els darrers anys.
L'objectiu de l'obra — dividida en quatre capítols als que se li sumen un breu pròleg- ja ens el deixa ben clar l'autor des del principi: el seu propòsit és actualitzar la idea d'educació democràtica que ens ha estat llegada per la tradició pedagògica occidental per tal d'adaptar-la a les exigències del present. La forma en què proposa portar a terme aquesta actualització, ens diu, és a través de la construcció i l'apregonament en una forma de vida que s'escapa de la lògica individualista, competitiva $i$ interessada consistent en congregar persones diferents al voltant d'una finalitat comuna $i$ en cooperar per tal d'aconseguir-la, sempre amb la vista posada en la cerca constant del bé de la comunitat. En aquest sentit, podrem començar a imaginar quina serà la manera de viure per la que apostarà en Josep Maria Puig quan declari que la finalitat de l'educació democràtica és abandonar l'homo ceconomicus i posar, al seu lloc, l'homo cooperans, tot oferint als joves, en una proposta en la que es deixen sentir certs ecos arendtians, «el papel de protagonistas de los cambios que han de llevarnos hacia otra forma de vida» (p. 13).

Però què és l'educació democràtica? Quins trets essencials la defineixen? De quina manera l'està entenent aquí l'autor? $J a$ a les primeres pàgines, $i$ abans d'analitzar les diverses aportacions que la tradició pedagògica ha llegat sobre aquesta idea, Josep Maria Puig afirma que en l'educació 
democràtica conflueixen com a mínim tres línies de política educativa i d'acció pedagògica complementàries: la participació dels implicats en cadascun dels nivells del sistema educatiu, la generalització no discriminatòria del dret a l'educació i el desenvolupament complet de l'individu com a persona i ciutadà. Aquesta caracterització, emperò, com no deixa pas d'advertir-nos, s'ha concretat de diverses maneres al llarg de la història, el que significa que quan parlem d'educació democràtica no estem davant una realitat fixa i acabada sinó que es tracta d'un concepte que està en evolució i que s'ha anat actualitzant progressivament a través de diverses aportacions complementàries al seu ideal.

Aquestes contribucions, dins les quals trobem les més rellevants pedagogies de I'últim segle (tradicional, activa, socialista, antiautoritària, crítica, del reconeixement...), conformen el que l'autor anomena com a «moments de l'educació democràtica», essent, tots ells, «un conjunto de momentos, cada uno de los cuales ha añadido elementos de crítica al ejercicio del poder disciplinario, la autoridad, la heteronomía y la inculcación ideológica» (p. 29). Tanmateix, i per bé que les mencionades pedagogies han suposat diferents i valuosos estadis en el concepte i la realitat de l'educació democràtica, part dels temps que ens ha tocat viure, caracteritzats, com veurem, per uns valors insostenibles, semblen voler assistir a les exèquies d'aquesta manera d'entendre l'educació. Fatalitat, no cal dir-ho, que tant el llibre que tenim entre mans com el seu autor volen contribuir a contrariar.

En efecte, la forta irrupció del neoliberalisme, construït al voltant d'una antropologia basada en una concepció utilitària de la naturalesa humana que es veu com racional, egoista i orientada a maximitzar el propi interès, situa, en la seva vessant politicoeconòmica, la llibertat individual — especialment en l'àmbit econòmic - i el mercat com els seus principals estendards. El neoliberalisme, en altres paraules, és un moviment cultural que transcendeix l'àmbit filosòfic, polític i econòmic, raó per la qual molts autors, com el mateix Josep Maria Puig, el consideren una manera d'entendre la vida i, per extensió, una proposta educativa «cuya intención es transformar la subjetividad y cambiar los valores de los seres humanos» (p. 38).

Així, el neoliberalisme, en tant que teoria i pràctica educativa, pretén implantar un sistema escolar individualista, mercantilista i competitiu preocupat per la formació de l'homo œeconomicus. Una educació, en definitiva, dominada per la lògica de l'acció humana calculadora i en la que

\footnotetext{
la economía es el método y, de modo más preciso, la generalización del mercado y de la competencia son los dispositivos que lo impregnan todo, las ideas que entran en la mente de los individuos y que, después de ocuparla, se transforman en hábitos que acaban dando forma al modo de ser humano. (p. 39)
}

D'aquesta manera s'observa amb prou claredat perquè una època dominada per les idees neoliberals és un terreny tòxic per la vitalitat i l'enriquiment de l'educació democràtica: davant la importància de la collectivitat, el neoliberalisme emplaça l'individu; davant la cerca conjunta del bé comú, la competitivitat. En el fons, tot plegat no és més que la conseqüència $d$ 'imposar l'acció calculadora com la única manera natural, obvia i evident d'entendre l'acció i la vida humana davant d'altres alternatives possibles.

Una d'aquestes possibilitats, la de l'acció comuna, és la que el nostre autor escull com alternativa sòlida a aquella forma de vida insostenible caracteritzada per l'individualisme competitiu de l'acció calculadora i del somni neoliberal. Què s'entén per acció comuna és, però, el resultat de tota una exposició anomenada El universo 
de lo común, que comença en la biologia, en considerar la cooperació com un dinamisme social arrelat a la nostra evolució que permet tant la moralitat com la cultura i acaba en la insistència de la filosofia contemporània per destacar l'existència i la importància d'un món comú, entès com un espai vital «hecho de significados, normas, lenguajes, costumbres, valores y prácticas sociales, en el cual estamos inscritos sin reflexión previa» (p. 97).

Entre l'exposició d'aquests dos àmbits conformadors de l'univers d'allò comú ens trobem amb reflexions de gran calat que s'introdueixen en diferents àrees del coneixement per tal d'abordar la resta de components que configuren dit univers: l'empatia i la cura com a trets d'identitat de la nostra espècie, el do com a dinamisme relacional capaç de produir humanitat, els bens comuns com a tipus especial de recurs regulat per la comunitat, i la democràcia i la participació com a maneres de viure i com a procediments compromesos a buscar collectivament, en forma d'acció comunitària, els millors mètodes per tal d'aconseguir les millors decisions sobre l'organització de la societat i la resolució dels problemes que li afecten

Malgrat I'heterogeneïtat percebuda, tots aquests àmbits de l'univers d'allò comú, ens diu en Josep Maria Puig, tenen una estructura semblant. En analitzar-los ens trobem, assegura, davant una lògica de l'acció comuna, és a dir, davant d'un procediment per enfrontar situacions problemàtiques que encarna un conjunt de valors i de pautes de conducta reconegudes pel fet d'aplegar persones al voltant d'un objectiu i de cooperar per tal d'aconseguir-lo. Aquesta primera aproximació a la manera com s'entendrà l'acció comuna, nucli fonamental de l'obra, és la que serveix de frontera entre tot el preàmbul teòric que fonamenta la proposta educativa del llibre i la proposta mateixa, anomenada Pedagogía de la acción común, expressió que dona nom tant al llibre com al quart i últim capítol del mateix. Així, tot partint de la definició d'acció comuna, que s'entén com

\begin{abstract}
un dinamismo social complejo que transforma una situación problemática en un reto colectivo $y$, para hacerle frente, activas capacidades destinadas a acomunar, deliberar y cooperar con el propósito de impulsar juntos un proyecto de intervención dirigido a solucionar el problema inicial y ejecutado en beneficio de la comunidad y de cada uno de los participantes. (p. 104)
\end{abstract}

Puig argüeix en l'última part del text que si l'educació democràtica té com un dels seus trets principals el desenvolupament integral de l'individu, l'acció comuna, en tant que experiència humana essencial, ha de ser incorporada com un motor formatiu insubstituïble. De fet, moltes són les experiències i les pràctiques pedagògiques que, al llarg de la història, han incorporat els dinamismes de l'acció comuna en les seves propostes. BadenPowell, I'Escola de Barbiana, Freire o la Pedagogia Institucional són només alguns exemples del que diem, a banda de les nombroses experiències innovadores que es recullen al llibre (p. 108-111). L'objectiu de totes elles, per això, és educar per a una altra manera de viure, això és, que l'educació es converteixi en un medi útil per tal que l'enigmàtica admonició continguda al final del famós poema de Rilke Tors arcaic d'Apol.lo, aquell «Has de canviar de vida», es faci realitat.

Ara bé, això, seguint la prevenció arendtiana, no ho podem fer nosaltres: ha de ser feina dels joves. Així ho creu també l'autor del llibre i per això afirma que la missió de l'educació és alliberar les forces imaginatives del joves $\mathrm{i}$ «confiarles la tarea de participar en la construcción de formes de vida que sustituyan las obsoletas» (p. 113). El que implica, atès que aquestes no- 
ves maneres de viure no poden ser ensenyades per nosaltres, que hem de "pasar de enseñar lo que sabemos a enseñar lo que desconocemos» (p. 113). Preparar per a la vida, avui, és ensenyar a canviar de vida, per la qual cosa la pedagogia de l'acció comuna «debe orientar el acto de aprender hacia la creación de lo por venir, de lo que todavía no existe, de lo nuevo» (p. 114). «Aprender es inventar» (p. 124), sentenciarà l'autor més endavant.

Però com no es pot inventar sobre el no-res, caldrà prendre l'actualitat, el present real, com a matèria d'estudi, com a currículum. D'aquí que una proposta educativa com la que tenim entre mans no escolaritzi els temes que tracta sinó que vagi a buscar-los directament, tot fent servir, com a llibre text, «la realidad tal cual se presenta y en el lugar donde se presenta» (p. 117) i com a mecanisme central del procés d'aprenentatge, el compromís crític i la intervenció col-lectiva sobre les problemàtiques reals i veritablement sentides de la societat. La manera com es durà a terme aquesta intervenció, tanmateix, no es pot conèixer per endavant. Aquesta és la raó per la que la pedagogia de l'acció comuna cultiva l'esperança creativa. La qual cosa no implica haver-ho de deixar tot a l'atzar sinó que, ben al contrari, impel.leix a contribuir activament a què els individus siguin capaços de canviar el seu marc cognitiu per tal d'enfrontar-se a problemes desconeguts, fins aquell moment irresolubles o impossibles d'imaginar per als adults.

Aquest compromís i responsabilitat per contribuir al naixement d'una vida millor sense saber per endavant com serà tal forma millor de vida és el que fa imprescindible, segons l'autor, incorporar alts nivells de reflexió a la pedagogia de l'acció comuna. La reflexió, de fet, és un mecanisme d'optimització de l'aprenentatge, una acti- vitat de segon ordre que ens permet «saber más, actuar con mayor acierto y dar mayor sentido personal y social a la actividad» (p. 127). Segurament, conscient com és de la importància de la reflexió en qualsevol iniciativa pedagògica, en Josep Maria Puig dedica unes pàgines - que hom ha trobat especialment interessants - a exposar què és la reflexió, quines tipologies de reflexió hi ha, i quin paper hi juguen en la presa de consciència i en la ineludible dotació de sentit que tot educand ha d'atorgar, per tal que l'acció comuna sigui veritablement educativa, a l'experiència viscuda i al conjunt de la vida dels participants.

La importància cabdal de la reflexió en aquesta proposta és encara més fefaent si tenim en compte que l'acció comuna, a banda de suposar tota una sèrie de consideracions de caire teòric sobre l'educació, és també una proposta ètica, una línia normativa de conducta d'índole pragmàtica que considera que «actuar de modo correcto es implicarse activamente en la resolución de los problemas prácticos que pueden plantearse en una situación singular» (p. 133). La qual cosa ens situa davant d'una ètica procedimental, intersubjectiva, pràctica i contextual que defuig les abstraccions, que es guia per tot un conjunt de valors implícits a l'acció comuna (sensibilitat, cura, cooperació, responsabilitat, altruisme...) i que té en la determinació col-lectiva dels fins de l'acció i en la transformació personal -recordeu el mandat rilkià - les seves principals insígnies.

Al capdavall ens trobem davant d'una ètica i d'una teoria de l'educació, a les que podríem titllar de pragmàticohumanístiques, que lliguen metodològicament amb les contribucions que els darrers anys el nostre autor, en conjunt amb altres col.legues, ha portat endavant. Em refereixo, com no pot ser d'una altra manera, a 
l'aprenentatge-servei, una reconeguda proposta educativa caracteritzada per unir aprenentatge i servei a la comunitat coincident, en estructura, amb la lògica de l'acció comuna en impulsar el pensament i l'actuació conjunta en benefici de la comunitat (Temps d'Educació va dedicar un monogràfic a l'aprenentatge-servei, el número 41 de 2011, en què va participar el professor Josep Maria Puig). I també a diferents consideracions i propostes sobre l'educació en valors i per a la ciutadania que, a banda de promocionar l'aprenentatge-servei com a pràctica educativa tant formal com no-formal, busca tenir en compte els diferents espais de l'educació en valors i articular-los en una proposta pràctica completa i actualitzada d'educació democràtica, propòsit principal, com es recordarà, del Ilibre que ens ocupa.

Així, quatre són els espais de l'experiència moral sobre els que l'educació democràtica ha d'impactar per tal que sigui el més completa i actualitzada possible: les relacions interpersonals, la deliberació i la cooperació necessàries en l'interior del grup-classe, la pertinença i la participació en la vida del centre educatiu, i les pràctiques de ciutadania, com el ja mencionat aprenentatge-servei, en tant que intervenció sobre les necessitats de la comunitat per a contribuir a pal-liar-les. Vet aquí, però, que totes elles, ben ruixades d'exemples i de propostes pràctiques per al seu treball durant l'exposició al llibre, només poden ser efectives, ens diu en Josep Maria Puig, si abans s'ha creat una cultura moral institucional i s'ha generat un ecosistema educatiu que vagi més enllà del centre, tot aplegant els diversos actors i institucions educatives i no educatives que tenen un important paper formatiu en la vida dels i les joves.
El llibre conclou amb un catàleg de vint-i-dues tesis per a una pedagogia de l'acció comuna que es presenten a mode de síntesi i de manifest d'una teoria, una ètica i una metodologia educativa coherent amb el desenvolupament teorètic precedent. I que demostren, un cop més, el gran talent sistemàtic al que ja ens té acostumats el seu autor. Deixem i animem als interessats la lectura fecunda i veritablement impel.lidora tant d'aquestes tesis com de la totalitat de l'obra. No sense abans - no ho podem evitar - transcriure una de les tesis a mode de resum del to $i$ del contingut general del llibre:

\begin{abstract}
La educación como acción común supone confiar en la capacidad creativa de los jóvenes para avanzar hacia otras formas de vida. En la medida que la educación implica a los aprendices en el cambio de las formas de vida obsoletas, los adultos deben confiar en sus capacidades de creación y transformación. Deben animarlos a definir nuevos marcos mentales y avanzar hacia mejores formas de vida. En la medida que la pedagogía de la acción común enfrenta al alumnado a problemas abiertos, está confiando en su capacidad para imaginar nuevas realidades $y$, aunque no siempre surgen innovaciones efectivas, siempre se vive la experiencia de enfrentarse a una realidad que precisa cambios cuya dirección no conocemos. ( $p$. 159)
\end{abstract}

Heus aquí l'aposta del professor Josep Maria Puig per educar en i per a una altra manera de viure. Ni més ni menys. 